\title{
Combating Counterfeiting of Medicines in the Republic of Belarus: Legal Analysis
}

\author{
PAVEL SASCHEKO
}

\begin{abstract}
Counterfeiting of medicines constitutes as a threat to public health, which nowadays has a "pandemic character". In this regard, the legislation of the Republic of Belarus should properly address the risks caused by counterfeited medicines. Being a member of several economic alliances aimed at simplifying turnover of goods, including medical products, Belarus needs to develop comprehensive preventive measures and provide effective and proportionate criminal and other sanctions for the commission of acts connected with counterfeiting of medicines. This article focuses on key factors which impact the development of Belarusian legislation. The main obstacles for effective international cooperation in criminal matters concerning turnover of counterfeit medicines are also explored. Amendments to legislation aimed at improving the effectiveness of combating counterfeiting of medicines will also be discussed.
\end{abstract}

Keywords: - medicine $\bullet$ counterfeiting of medicines $\bullet$ crime $\bullet$ criminal liability $\bullet$ administrative liability $\bullet$ Belarus

CorRespondence Address: Pavel Sascheko, Ph.D, Scientific Center of the Prosecutor General's Office of the Republic of Belarus, 76 Zakharova str., 220088 Minsk, Belarus, e-mail: pavel_sascheko@mail.ru.

https://doi.org/10.18690/2463-7955.10.2.85-104.2017 ISSN 2463-7955

(C) 2017 University of Maribor Press

Available at http://journals.um.si/index.php/medicine. 

P. Sascheko: Combating Counterfeiting of Medicines in the Republic of Belarus: Legal Analysis

Article 45 of The Constitution of the Republic of Belarus ${ }^{1}$ guarantees the right of the citizens to health care. Effectively combating the counterfeiting of medicines is one of the vital factors in which to ensure the realization of this constitutional right. Therefore, the state should develop a legal framework which is aimed at the protection of people from the appearance of counterfeit medicines on the Belarusian market of medical products. The principal legal act in the field of turnover of medicines is the Law of the Republic of Belarus of 20 July 2006 "On medicines". ${ }^{2}$ Other regulations have been adopted as well. One example is the Resolution of the Council of Ministers of the Republic of Belarus of 22 December 2009 No 1677, which prescribes the procedure for the withdrawal of counterfeit medicines from turnover and their destruction. ${ }^{3}$

It should be noted that the development of relevant legislation in Belarus is influenced by its participation in several international alliances: the Eurasian Economic Union (the EEU), the Commonwealth of Independent States (the CIS), and the Union State of Belarus and Russia. As a result of their activities, the harmonization of civil, criminal, administrative and other legislation is taking place.

For example, in accordance with the Treaty on the EEU, ${ }^{4}$ the common market of medical products was established on 1 January 2016 based on the principles of harmonization of legislations of member states and the application of unified rules for evaluation of quality, effectiveness, and safety of medicines (article 100). Various legal acts were adopted with a view to enable proper functioning of the common market, including simplification of trade and distribution of medicines. For example, under Clause 7 of Article 7 of the Agreement on Common Principles and Rules of Turnover of Medicines within the EEU, the member states recognizethe registration of medicines, the results of pre-clinical, clinical and other examinations of medicines, and the results of manufacturing inspections which have been conducted in another member state ${ }^{5}$.

As a member of the Union State with Russia, Belarus has no border with the Russian Federation, so counterfeit medical products from Russia have virtually no obstacle in the course of their import into Belarusian territory, and vice versa. Common measures need to be addressed in order to solve this problem. However, this process can be complicated in part because Belarus and Russia sometimes take different measures in the way they fight against falsification of medicines. For example, Russia has signed the Council of Europe Convention on the Counterfeiting of Medical Products and Similar Crimes involving Threats to the Public Health adopted on 28 November 2011 (the Medicrime Convention), ${ }^{6}$ while Belarus has not.

However in recent years some legal issues of turnover of medicines in Belarus have been a subject of scientific research (Reutskaja, 2016; Rocheva, 2014; Rocheva, 
2016; Sherjakov, 2009), but the legal dimensions of fighting against counterfeiting of medicines has not been examined. Having in mind the legal issues mentioned above, practical need and almost complete absence of the relevant studies, issues regarding legal measures for prevention and combating counterfeiting of medicines and international cooperation in criminal matters merits examination. This article is aimed at a comprehensive overview of Belarusian legal regulation aimed at combating counterfeiting of medicines. The article is divided into three section. In the first section, preventive measures provided for by domestic legislation and international treaties of Belarus are examined. The criminalization of counterfeiting of medicines and administrative sanctions for similar acts are explored in the second section, while the third section deals with international cooperation in criminal and administrative matters.

\section{Preventive Measures}

As the well-known saying goes, an ounce of prevention is better than a pound of cure. So, it is natural that both practitioners and theorists are in constant search of the most effective and comprehensive measures aimed at the prevention of the manufacturing and appearance of falsified medicines on the market.

Belarusian Law on medicines contains a set of measures aimed at providing quality of medicines, including registration of medicines; licensing of pharmaceutical activity; system for medical product quality inspection and for pharmaceutical supervision (supervision aimed at detection of changing in effectiveness and risks of application of medicines); use of supervision system for manufacturing environment, conditions of producing of medicines in pharmacies, transportation and application of medicines in health care institutions; elaboration and implementation of Good Manufacturing Practices, export and import rules.

However, in reality these measures have some weak points. The quality control system of goods which are manufactured, imported, and distributed, focuses on the control of legally-established and law-abiding entities. As E. I. Shornikov points out, in Russia there were cases of distribution of falsified medicines which had on their package exactly the same serial number as those medicines that were lawfully distributed and certified for distribution (Shornikov, 2011: 37-38). In these cases, the quality control system often can be ineffective. Sometimes unimpeded delivery of counterfeit medicines to the consumer is ensured by bribes (Rocheva, 2016). Moreover, it is necessary to take into account that measures provided for by the Law were not elaborated to prevent counterfeiting of medicines. These measures can be considered just as supplementary ones.

The crucial role is to be played by preventive measures, which are specially designed to fight against falsifying medicines as a sort of illegal activity. In 2005 Belarus introduced a very important measure which can serve as a good example: 
P. Sascheko: Combating Counterfeiting of Medicines in the Republic of Belarus: Legal Analysis

the requirement to import medical products directly from producer or his official distributor. As Sherjakov stated in 2009, the counterfeit medicines had been detected on Belarusian market only from 1999-2004, and after 2005 there were no such medicines (Sherjakov, 2009). The effectiveness of these measure was confirmed in 2017 by Reutskaya, head of department for pharmaceutical inspection and organization of medicinal support of the Ministry of Health, who said in an interview that for the past ten years there have been no incidents of detection of counterfeit medicines in Belarus due to the fact that they have been imported only directly from the manufacturer or via distributors (Kostiukevich, 2017). It should be noted as well, that shortening the chains of distributors of medicines is one of the measures aimed at prevention of dissemination of falsified medicines, which has been offered recently in Russian scientific literature (Aksenova-Sorohtej et al., 2016: 147).

However, the absence of cases of detection does not mean that there is no necessity to enhance the existing organizational and legal system of counteraction of falsification of medicines. It should be added that these crimes are often latent.

Some effective measures aimed at prevention of falsifying medical products can be found in international agreements to which Belarus is a state-party.

In the CIS, such measures mainly focus on joint actions and are executed under the Agreement on Cooperation in the Fight against the Turnover of Counterfeit Medicines. ${ }^{7}$ It provides for the exchange of information concerning means and methods used to conceal counterfeit medicines during transportation and selling; exchange of information regarding methods for detecting such medicines; harmonization of legislation in accordance with international standards and WHO recommendations; development of methods for controlling the quality of medical products and detecting counterfeit medicines (Strban, 2016); development of training programmes for personnel responsible for fighting against the turnover of counterfeit medicines; provision of technical assistance and assisting one another in introducing modern protective technologies including marking of medicines.

Within the EEU, the basis for cooperation is the Agreement on Unitary Principles and Rules for Turnover of Medicines in the EEU. ${ }^{8}$

The detailed procedure for cooperation is provided by the Decision of the Council of Eurasian Economic Commission of 3 November 2016 No 86 "On Procedure for the cooperation of member-states of Eurasian Economic Union in detection of counterfeit medicines, medicines infringing intellectual property rights or suffering from quality defects". ${ }^{9}$

Decision No 86 prescribes the establishment of contact points of member states and creation of the integrated database of the EEU. Article 13 of the Agreement on 
Unitary Principles obliges each state party to immediately inform Eurasian Economic Commission and competent authorities of the state parties about detection of counterfeit medicines and to take necessary measures for withdrawal of them from turnover.

Belarusian Law on medicines provides that it is the Ministry of Health of the Republic of Belarus which is in charge of withdrawing false medicines from turnover. The procedure for the withdrawal of counterfeit medicines from turnover and destruction of them is prescribed in details in the Resolution of the Council of Ministers of the Republic of Belarus of 22 December 2009 No $1677 .{ }^{10}$

One more important measure, which was prescribed in the Decision No 86, was the establishment of the integrated database of the EEU. The database is comprised of several databases: the database on medicines suffering from quality defects or infringing intellectual property rights and counterfeit medicines which are detected in member-states; the database on medicines which registration certificates has been suspended, medicines recalled or prohibited for medical use in member-states; and the database on registered medicines of the Union.

Information on detection of a counterfeit medicine includes:

- the member-state and the entity where a counterfeit medicine has been detected; name and address of manufacturer marked on the label; name of the supplier and a state where it is situated;

- the trade mark used (in accordance with a register of a member state or the unitary register of the EEU) and international nonproprietary name;

- number of medicines detected; the pharmaceutical dosage form of a medicine, dosage; formulation; model of the package; number of a batch, date of manufacturing, and validity term indicated on package;

- description of signs of counterfeiting (a photo, sample of a counterfeit medicine, etc.);

- actions which were made by competent authority of the member state where such a medicine was detected.

Effective functioning of the database requires a uniform understanding of what the objects are, which are considered as counterfeit medicines. However, it should be admitted that there is no unified definition of a counterfeit medicine in member states of the EEU.

For instance, in the Republic of Belarus, the Law on medicines defines a counterfeit medicine as a medicine which is intentionally accompanied with a false representation, such as the composition and/or manufacturer. Identical notion is given in article 4 (clause 37) of the Federal Law of the Russian Federation "On the turnover of medicines". ${ }^{11}$ However, in the Code of the Republic of Kazakhstan on 
P. Sascheko: Combating Counterfeiting of Medicines in the Republic of Belarus: Legal Analysis

People's Health and Health Care System the following definition is given: falsified medicinal product, medical device and medical equipment - medicines, medical device and medical equipment, unlawfully and intentionally supplied with false information and fake label about their composition or configuration and (or) manufacturer, and also secretly manufactured. ${ }^{12}$

In addition, Decision of the Council of Eurasian Economic Commission of 3 November 2016 No 80 "On approval of Good distribution practice of the Eurasian Economic Union ${ }^{13}$ defines a counterfeit medicine not only as a medicine intentionally accompanied with a false representation as regards composition and/or manufacturer but as a medicine accompanied with a false representation as regards the supply including records and documents concerning distribution channels.

The possible consequence of existing differences in respect of definitions can be the situation where states will detect different types of medical products considered as counterfeit medicines and collect dissimilar data about them. So, there is a risk of inserting non-uniform data from member states into the integrated database created in the EEU under the Decision No $86 .^{14}$

One of the ways to solve the problem concerning unified definition is to amend the related domestic legislation of member-states in accordance with the Decision No 80. However, it should be taken into account that several members of the CIS and the EEU are state parties to the Medicrime Convention. For instance, such CIS countries as Armenia, the Republic of Moldova and Ukraine ratified the Convention.

The Medicrime Convention provides definitions of the following; medical product, medicinal product, and medical device. It also states that the term "counterfeit" shall mean a false representation as regards identity and/or source. It is clarified in the Explanatory Report to the Medicrime Convention that an adulterated medical product (i.e. a medical product - usually a powder or a liquid - made poorer in quality by intentionally adding or substituting another undeclared substance) shall be considered as counterfeit; the term "adulterated medical product" is not regarded as notion distinct from "counterfeit medical product". ${ }^{15}$ The term "source", in accordance with the Explanatory Report, is understood in a broad sense, including the supply and distribution history of the medical product, active substance, excipient, part, material or accessory.

Since it is not clear from the Belarusian Law on medicines if the term "counterfeit medicine" covers adulterated medicines or false representation regarding supply and distribution history, it should be amended to facilitate unified and unambiguous understanding and application of this term. Similar changes can be introduced into legal acts of the EEU, including Decision No 80. This will enable more effective prevention of counterfeiting of medicines in terms of international cooperation. 
Decision No 80 is a very important legal act on the EEU level not only because it provides the definition of a counterfeit medicine, but because this act contains requirements to the quality management aimed at the impossibility of falsifying medicines while they are being transported or stored. It prescribes rules regarding due decision-making process, special training of staff, the isolation of counterfeit medicines from the other medicines, measures for saving the identity of medicines, special rules in respect of the distribution of medicines vulnerable to counterfeiting, and coordination of participants of distribution during the process. It also provides for the information exchange about detection of counterfeit medicines; procedures to avoid falsification of medicines returned to the supplier, documentation of all actions involving counterfeit medicines, risk assessment requirements and requirements for the transportation of medicines. All of these measures are specifically designed to fight against counterfeiting of medicines and they should be provided for by domestic legislation of the Republic of Belarus.

Even though national legislation and legal acts of the EEU and CIS provide for a number of measures aimed at the prevention of falsification of medicines, some additional measures are offered in the scientific legal literature (e.g. publication of information about detection of falsified pharmaceutical products; on-line publication of data on pharmaceutical companies obtained licenses for wholesale trade, etc.) (Kagadeeva, 2015: 428). Kopytin indicated that Russian legislator also should take into account European experience in prevention of counterfeiting of medicines, for example some measures provided for by Directive 2011/62/EU of 8 June 2011 could be introduced (e.g. obligation of wholesale distributors to verify their supplying wholesale distributors; accreditation of web-cites of pharmacies, etc.) (Kopytin, 2012: 10-13).

Thus, legal regulation concerning prevention of counterfeiting of medicines should be improved in the Republic of Belarus. First of all, the definition of counterfeit medicine provided for by the Law on medicines should be amended. Secondly, a separate article focused on prevention of counterfeiting of medicines needs to be introduced in the Law to enhance public awareness about the problem. Thirdly, further elaboration of the legal framework can be achieved by creation of a law which will comprehensively cover all issues aimed at prevention of counterfeiting of medicines, including measures aimed at staff training; enhancement of public awareness of traits of counterfeit medicines; development of marking; requirements to distributors and suppliers of medicines; cooperation with law-enforcement bodies; procedures regarding databases, keeping of falsified medicines, etc.

\section{Criminal and Administrative Offences}

Effective fighting against counterfeiting of medicines is impossible without a set of criminal and administrative measures. Analysis of the Criminal Code (the CC) of the Republic of Belarus demonstrates that several articles of the Code can be used 
P. Sascheko: Combating Counterfeiting of Medicines in the Republic of Belarus: Legal Analysis

to some extent with a view of fighting against counterfeiting of medicines. ${ }^{16}$

Article 335 of the $\mathrm{CC}$ in paragraph 1 criminalizes illegal treatment or pharmaceutical activity conducted as a profession by a person who does not have a license if such actions caused by negligence the bodily harm of average gravity. Paragraph 2 of the article provides criminal liability for the same act, in which a person had grave bodily harm or even death because of negligence.

It should be noted here that the term "pharmaceutical activity" is defined in article 1 of the Law of the Republic of Belarus "On Health Care" as activity conducted by legal entities or entrepreneurs in the field of turnover of medicines, pharmaceutical substances or plant feedstock materials in accordance with rules established by legislation of the Republic of Belarus. ${ }^{17}$

Though illegal pharmaceutical activity entails some acts which involve counterfeiting of medicines, numerous actions are not covered by article 335 of the $\mathrm{CC}$, because the scope of criminal liability is limited by the elements "conducted as a profession by a person who does not have a license", "if bodily harm of average gravity is caused by negligence". It is evident however, that counterfeiting of medicines can be committed by a person who has obtained a license. Moreover, use of a counterfeit medicine does not necessarily cause harm to the health of a person. As Khasanov indicates, experts divide counterfeit medicines into three types: medicines which do not contain any active substance; medicines which contain a falsified active substance or contain less active substance then genuine ones as well as medicines copying the form of originals; and medicines with expired shelf life (Khasanov, 2015: 49-51). He also states that the medicines of the first type are the safest among falsified ones (Khasanov, 2015: 49-51). So, if a disease is not grave, a person can recover even without medicines. It is necessary to add that medicines can also be used to diagnose health, to ensure medical rehabilitation or even to prevent pregnancy; in such cases falsified medicines do not necessarily cause harm to health.

Article 337 of the CC prohibits production or sales of products of poor quality. This criminal offence encompasses putting of poor quality products on the commodity market, the sale of such products to consumers, if these acts are capable of causing illnesses or poisoning of people, or if such products are contaminated with radioactive nuclides in extent exceeding allowed level. A person is criminally liable for the acts indicated in the article if the acts are committed within one year after an administrative sanction was imposed on him or her for the same acts. Paragraphs 2 and 3 of Article 337 of the CC contain such aggravating circumstances as causing grave bodily harm or bodily harm of average gravity or death of a person (in such cases prior administrative liability is not a necessary pre-condition for criminal liability). 
The most significant shortcoming of Paragraph 1 of Article 337 of the $\mathrm{CC}$ is that the imposition of an administrative sanction is established as a pre-condition for criminal liability. It limits the abilities of law enforcement bodies to stop the illegal activities, as offenders are generally not afraid of losses caused by the imposition of administrative sanctions, because counterfeiting of medicines is a highly profitable activity. Moreover, Article 337 does not cover all actions connected with counterfeiting of medicines, because the terms "products of poor quality" and "counterfeit medicines" differ in meaning.

The manufacturing of counterfeit medicines if this act is not connected with placing falsified medicines on commodity market or selling to consumers is also not in the scope of Article 337 of the CC. As indicated in the Commentary to the CC of the Republic of Belarus, the acts provided for by Article 337 of the CC constitute a criminal offence if they are committed by a public official of a legal entity, an entrepreneur, or a person who is in charge of sales (shop assistants) (Ahramenka et al., 2010: 778). Thus, Article 337 of the CC cannot be applied in a situation where counterfeiting is committed by a "normal" person who is not a public official, an entrepreneur, or is not in charge of sales.

Article 337 of the $\mathrm{CC}$ is not an effective instrument against counterfeit medicines, because similar to Article 335 of the $\mathrm{CC}$, the use of counterfeit medicines that do not cause illnesses, poisoning of people or harm to health in all cases, the law cannot be applied.

Article 248 of the CC prohibits the illegal use of trademark (service mark), business name, geographical identification of a competitor, or sale or offer for sale of a good (service) using cautionary marking with respect to a trademark not registered in Belarus. The same goes for the copying of industrial models, which entails confusion of production (goods, works or services), or activity with ones produced by a competitor if these acts are committed intentionally, and if they are committed during the period of one year after an administrative sanction was imposed on a person for the same act. The crux of the article is that these acts give rise to criminal liability only in cases when they are committed by a public official of a legal entity or an entrepreneur. The scope of application of this article is also limited, since counterfeiting of medicines can be committed by persons not registered as entrepreneurs or without the establishment of a legal entity; there is also a requirement of prior imposition of administrative sanction for the same acts as a necessary pre-condition for criminal liability.

In a limited number of cases, Article 257 of the $\mathrm{CC}$ of Belarus can be applied to punish illegal activities connected with counterfeiting of medicines. According to this article the following acts are prohibited: deceit of customers, clients or other consumers by an employee of an entrepreneur or legal entity selling goods, fulfilling works or providing services; deceit of consumers by an entrepreneur who carried 
P. Sascheko: Combating Counterfeiting of Medicines in the Republic of Belarus: Legal Analysis

out the activities mentioned above. These acts are punishable if they are committed within one year after an administrative sanction was imposed on a person for the same act or if the acts are committed on a significant scale. Article 257 specifies the following aggravating circumstances: commission of the offence by a group of persons by prior collusion or by a person convicted for the same act previously and commission of the offence on a large scale.

As the $\mathrm{CC}$ of Belarus does not properly address the issue of counterfeiting of medicines, the development of effective and dissuasive measures against counterfeiting of medicines is one of the topical issues for the republic. The latest developments in the field under consideration in the Russian Federation merit particular attention due to existing similarities of Belarusian and Russian criminal codes, which stem from their common Soviet roots and strong economic, social and political ties between two countries. Contrary to the approach used in the CC of Belarus, the Criminal Code of the Russian Federation contains specific provisions aimed at fighting against counterfeiting of medicines. ${ }^{18}$

The Russian Federation introduced criminal liability for turnover of counterfeit medicines, medicines of poor quality, or medicines not registered, for turnover of such medical items as well as for turnover of counterfeit biologically active supplement. Article 238.1 of the CC of Russia criminalizes the following acts if they are committed on a large scale (the value of products should exceed 100000 roubles): manufacturing, sale or import of counterfeit medicines or medical items to the territory of Russia; sale or import of medicines of poor quality or medical items to the territory of Russia for the purpose of sale; illegal manufacturing, sale or import to the territory of Russia of counterfeit biologically active supplement which contain pharmaceutical substances not claimed during state registration.

Paragraph 2 of Article 238.1 of the CC of Russia contains such aggravating circumstances as the commission of the offence by a group of persons by prior collusion or by an organized group, entailing through negligence grave bodily harm or death of a person. Paragraph 3 of the article establishes criminal liability for the commission of the act indicated in Paragraphs 1 or 2 of the article if the act entailed through negligence the death of two or more persons.

Article 327.2 of the CC of Russia establishes criminal liability for manufacturing (for the purpose of using or selling) or using of forged documents related to medicines or medical devices (registration certificate, certificate of conformance, instruction for use or normative, technical or maintenance documentation of manufacturer (producer) of medical article). Paragraph 2 of article 327.2 prohibits manufacturing (for the purpose of sale or use) or using of knowingly forged primary and/or secondary (consumer) package of a medicine. Paragraph 3 of Article 327.2 of the CC of Russia contains such aggravating circumstances as the commission of the offence by a group of persons by prior collusion or by an organized group. 
In addition Article 235.1 of the CC of Russia provides criminal liability for illegal manufacturing of medicines or medical devices (without permit or license if obtaining them is obligatory). Paragraph 2 of the article stipulates as aggravating circumstances commission of the offence by an organized group as well as the commission of the offence on a large scale.

Though the CC of Russia criminalizes counterfeiting of medicines and related crimes, it has some shortcomings and gaps. For instance, as Maksimov indicates, the fact that the legislation of the Russian Federation does not provide for any grounds for criminal or administrative responsibility for the export of counterfeit medicines from the Russian Federation, this is not in line with international legal norms (Maksimov, 2014: 86). At the same time, it should be noted that export actions may be partially covered by elements of "manufacturing" and "sale", though situations of exclusively exporting counterfeit medicines abroad are possible.

Russian scientist Godunov notes another shortcoming of the CC of Russia. In accordance with existing rules, less dangerous manufacturing of medicines without special permission (license), if such permission (license) is mandatory, (Paragraph 1 of Article 235.1 of the CC) can be punished more severely than the more dangerous manufacturing of counterfeit medicines (Paragraph 1 of Article 238.1 of the $\mathrm{CC}$ provides for a milder form of punishment - compulsory works, which is absent in paragraph 1 of article 235.1 of the $\mathrm{CC}$ ). He also points out that such element of the criminal offence provided for by article 238.1 of the $\mathrm{CC}$ as "committed on a large scale" can be an obstacle for punishing persons involved in cases where the value of illegal products less than 100.000 roubles, though the products are dangerous for health (Godunov, 2015).

In the process of development of domestic legislation Belarus also should take into account provisions of the Medicrime Convention, which constitutes one of the best international standards in the field.

For example, specific provisions can be introduced in the Belarusian legislation which will establish criminal offences when committed intentionally, acts described in article 6 of the Convention (the supplying or the offering to supply, including brokering, trafficking, including keeping in stock, importing and exporting of counterfeit medical products, active substances, excipients, parts, materials and accessories) and in Article 7 (the making of false documents or the act of tampering with documents when committed intentionally).

It should be added here that in accordance with Article 4 of the Convention, the term "document" means any document related to a medical product, an active substance, an excipient, a part, a material or an accessory, including the packaging, labeling, instructions for use, certificate of origin or any other certificate 
P. Sascheko: Combating Counterfeiting of Medicines in the Republic of Belarus: Legal Analysis

accompanying it, or otherwise directly associated with the manufacturing and/or distribution thereof. The criminalization of falsifying documents related to medicines can be viewed as one of the fundamental pillars for effective fighting against counterfeiting of medicines. Though the $\mathrm{CC}$ of Belarus establishes criminal liability for forgery of official documents granting right or relieving from duty or for the use of forged documents or sale of thereof (Article 380) and forgery by an official (Article 427), the scope of these articles is limited to so called official documents only. Packages, labels, instructions for use and some other documents associated with medicines cannot be considered as official documents in terms of elements of criminal offences provided for by Articles 380 and 427 of the CC of Belarus. It should be noted that the similar problem had existed in the CC of Russia before introducing to the $\mathrm{CC}$ the Article 327.2, providing criminal liability for making false documents related to medical products. As Maksimov indicates, at that time falsification of documents had been a criminal offence in accordance with Article 327 of the CC of Russia, but documents related to medical products (e.g. labels, instructions for use, etc.) had not been recognized by judges as the element "documents" of the criminal offence provided for by Article 327 of the CC (Maksimov, 2014: 86).

Thus, the Republic of Belarus faces the necessity of improving domestic legislation related to criminal liability for counterfeiting of medicines and for related crimes. The provisions of the CC of the Russian Federation, the Medicrime Convention, and other foreign and international legal instruments can be used in this process.

The Code of the Republic of Belarus on Administrative Offences (CAO) ${ }^{19}$ provides some tools which can also be used for fighting against counterfeiting of medicines. In this respect Articles 12.16 (deceit of consumers), 11.26 (illegal use of business reputation of a competitor), 16.7 (putting or sales of products of poor quality) require specific attention.

The description of the administrative offences in the CAO is similar to the description of criminal offences in Articles 257, 248 and 337 of the CC. The difference is that Article 257 of the $\mathrm{CC}$ names "significant scale" as one of the alternative elements of the offence and both Articles 257 and 337 contain aggravating circumstances (in the case of significant scale or presence of aggravating circumstances a person is criminally liable even if an administrative sanction has not been imposed previously).

Imposing administrative sanctions in accordance with these articles of the CAO is a necessary pre-condition for criminal liability under Articles 257, 248 or 337 of the $\mathrm{CC}$ correspondently if the same act is committed during one year after imposing an administrative sanction.

The articles mentioned above do not cover all possible acts related to counterfeit 
medicines. Furthermore, the simplified procedure used in an administrative process is not appropriate to detect and prove such sophisticated activity as counterfeiting of medicines, since such activity is often committed by organized criminal groups and involves the use of laboratories and special equipment.

Article 15.42 of the CAO provides for administrative sanctions for infringement of requirements to transportation, storage or use of medicines, biological preparations or other veterinary agents. But the word "other" in Article 15.42 indicates that this article does not cover acts in respect of medicines for human use. As a result, it needs to be amended to ensure application of this provision to the cases of infringements of requirements to transportation, storage or use of medicines for humans.

Further enhancement in the field can be achieved by introducing administrative liability for violation of rules in respect to distribution of medicines vulnerable to counterfeiting, procedures established for the exchange of information on counterfeit medicines, requirements of isolated storage of counterfeit medicines from other medicines, procedures in respect of documentation on actions involving counterfeit medicines, etc. (if such act or omission does not constitute a criminal offence). The necessity of introducing administrative liability for acts mentioned above can be supported by facts detected in practice of Russian prosecutor's bodies. Sharova points out that the analysis of materials shows that state bodies responsible for quality control do not always trace actual destruction of counterfeit medicines and do not react properly in all cases to information about poor quality medicines, etc. (Sharova, 2009: 30).

Some other possible problems can be illustrated by the Russian experience. In accordance with article 6.33 of the Code of the Russian Federation on Administrative Offences, administrative liability is established for turnover of counterfeit medicines, pirate copies of medicines, medicines of poor quality or medicines not registered, medical devices as well as for turnover of counterfeited biologically active supplements. ${ }^{20}$ The key distinctive feature between criminal offence specified in Article 238.1 of the CC of the Russian Federation and Article 6.33 of the Code on Administrative Offences is that an act constitutes a criminal offence if it is committed on a large scale. As a result, criminals can try to escape criminal liability by selling small batches of counterfeit medicines or by producing cheap products - e. g., a counterfeit medicine which does not contain active substance can be inexpensive.

Overall, the analysis shows that currently there is a room for improvement of both criminal and administrative legislation in the field of combating the counterfeiting of medicines. In this regard, amendments to the $\mathrm{CC}$ should be made in order to fill existing gaps in criminalization. Administrative liability for infringements creating favorable conditions for counterfeiting of medicines should be introduced as well. 
P. Sascheko: Combating Counterfeiting of Medicines in the Republic of Belarus: Legal Analysis

\section{International Cooperation}

The Republic of Belarus has necessary legal framework to ensure active and efficient international cooperation with other countries. Several international treaties create the legal basis for cooperation in prevention of counterfeiting of medicines in the CIS and the EEU. Belarus is also a member-state to specific conventions and bilateral treaties that create framework for providing mutual legal assistance.

Talking about the latter, it is worth noting that Belarus is a party to conventions on legal assistance in civil, family and criminal matters concluded among CIS countries in 1993 and 2002, and the United Nations Convention against Transnational Organized Crime (UNTOC). ${ }^{21}$ Belarus concluded bilateral treaties on mutual legal assistance in criminal matters with Lithuania, Latvia, Poland, Egypt, China, Serbia, etc. The Code of Criminal Procedure of the Republic of Belarus (CPC) contains provisions on international cooperation in criminal matters as well. ${ }^{22}$ Moreover, Belarus participates in some inter-governmental agreements and agreements between law enforcement bodies on combating criminality (generally on information exchange and cooperation between law enforcement bodies).

Article 2 of the Law of the Republic of Belarus "On international legal assistance in criminal matters" names international treaties and principle of reciprocity as grounds for legal assistance in criminal matters. ${ }^{23}$ Belarusian CPC, in the same way as multilateral and bilateral international treaties, contains provisions on requests for mutual legal assistance, extradition, transfer of criminal proceedings, etc. The existing legal framework allows taking evidence, executing searches and seizures, providing evidentiary items and expert evaluations, providing original and certified copies of documents, etc. Legal assistance can take place on the basis of reciprocity as well.

Some existing lacunas and shortcomings in the criminalization of counterfeiting of medicines and related acts create an obstacle for effective international cooperation. The main issue is the requirement of dual criminality which is usually indicated in multilateral and bilateral agreements as a precondition for extradition, transfer of criminal proceedings, etc. For instance, as Klimenko and Tretjakova point out, the Russian Federation did not have a legal basis for recognition of counterfeiting of medicines as a criminal offence and for providing mutual legal assistance in criminal matters until counterfeiting of medicines was criminalized in Russia in 2015 (Klimenko \& Tretjakova, 2015). It should be noted in this regard that this statement is vulnerable to criticism, because some acts had been criminally liable under other articles of the CC of Russia, whereas some acts had not been. So, mutual legal assistance could be provided in some cases taking into account that differences in description of criminal offences in accordance with international law cannot be considered as a reason for refusal of legal assistance. 
In order to use the mechanism of international legal assistance for crimes connected with counterfeit medicines, it is necessary to consider the definition of the organized criminal group and to assess sanctions stipulated in the CC.

As counterfeiting of medicines is usually committed by organized criminal groups and criminal organizations, the UNTOC can be used as a legal basis for mutual legal assistance in criminal matters with regard to taking evidence, effecting service of judicial documents, executing searches and seizures, and freezing, etc. (Article 18) and for extradition (Article 16).

As specified in Article 3 Paragraph 1 (a) and (b) of the UNTOC the scope of its application encompasses the offences established in accordance with articles 5 (criminalization of participation in an organized criminal group), 6 (criminalization of the laundering of proceeds of crime), 8 (criminalization of corruption) and 23 (criminalization of obstruction of justice) of the UNTOC and serious crime as defined in article 2 of the UNTOC where the offence is transnational in nature and involves organized criminal group. According to the Article 2 (b) of the UNTOC the term "serious crime" means "...conduct constituting an offence punishable by a maximum deprivation of liberty of at least four years or a more serious penalty". However, offences specified in Paragraph 1 of Article 335 and Paragraph 2 of Article 337 of the $\mathrm{CC}$ are punishable by a maximum deprivation of liberty of three years, whereas Paragraph 1 of the Article 337, Articles 257 and 248 do not contain such punishment as deprivation of freedom at all. Only sanctions of Paragraph 2 of Article 335 and Paragraph 3 of Article 337 of the CC contain maximum deprivation of liberty up to five years, and offences provided for by them are covered by the scope of application of the UNTOC.

Article 2 (a) of the UNTOC defines organized criminal group as "...a structured group of three or more persons, existing for a period of time and acting in concert with the aim of committing one or more serious crimes or offences established in accordance with this Convention, in order to obtain, directly or indirectly, a financial or other material benefit". However, Paragraph 1 of Article 18 of the CC of Belarus states that an organized group consists of two or more persons who united to form a stable operating group for conducting joint criminal activity. This inconsistency can create obstacles for international cooperation, because in a case where actions do not constitute several criminal offences, they cannot be considered as "criminal activity". Accordingly, the required element of an organized criminal group is absent, and the UNTOC is not applicable in cases where organized criminal groups are not involved.

Some agreements concluded by the Republic of Belarus contain provisions on cooperation in administrative matters, for instance the Agreement on Legal Assistance and Cooperation of Customs Offices of Member States of Customs Union in Criminal Matters and Matters on Administrative Offences ${ }^{24}$. This 
Agreement can be used as a legal basis for combating administrative offences involving smuggling of counterfeit medicines. But taking into consideration simplified procedure used in administrative process and lacunas in the CAO, mutual legal assistance in administrative matters cannot be considered as an effective measure for combating counterfeiting of medicines.

In general, the existing legal framework allows effective cooperation between states in cases related to fighting against counterfeiting of medicines. Existing shortcomings and gaps in the $\mathrm{CC}$ of Belarus regarding criminalization can be fixed by legislative changes taking into account international and foreign legislative, as well as practical experience.

\section{Conclusion}

The present study demonstrates that although Belarusian legislation contains various provisions that can be used for combating counterfeiting of medicines, they are not fully appropriate with regard to contemporary forms of illegal activity. Amendments to the Law on medicines directly aimed at combating manufacturing and distribution of counterfeit medicines are needed. It is also necessary to take steps to implement into domestic legislation the provisions on prevention of counterfeiting of medicines stipulated in the Decision No 80 and the Agreement on Cooperation in Fight against Turnover of Counterfeit Medicines. This will allow for more effective fighting against counterfeiting of medicines both on national and international levels.

The criminal offences of counterfeiting of medicines and counterfeiting of documents related to medicines (labels, packages, instructions for use, certificate of origin, etc.) need to be introduced in the CC of Belarus in separate articles. Elements of criminal offences, which limit criminal liability, should not be used in order to provide the effective scope of criminalization.

Taking into account that counterfeiting of medicines and related offences are often committed by organized criminal groups and criminal organizations, the applicability of the UNTOC is crucial. Criminal offences regarding counterfeiting of medicines in the CC should be considered as "serious offences" in accordance with the UNTOC. Administrative sanctions should be introduced for violation of procedures of legal turnover of medicines and procedures designed to prevent counterfeiting of medicines. Such sanctions can be used as a supplementary legal instrument which should not interfere with criminal liability.

The legal terminology in respect of counterfeit medicines should be clarified to ensure that the term "counterfeit medicines" in domestic legislation explicitly covers adulterated medicines, falsified substances and excipients, false information about records and documents concerning distribution history. The measures 
mentioned above not only will enhance domestic legislation against counterfeiting of medicines and related offences, but will also improve international cooperation of the Republic of Belarus in the field.

\section{Notes}

1 Konstitucija Respubliki Belarus' (1994), available at: http://pravo.by/pravovayainformatsiya/normativnye-dokumenty/konstitutsiya-respubliki-belarus/ (October 11,2017)

${ }^{2}$ Zakon Respubliki Belarus "O lekarstvennyh sredstvah", 20.07.2006 No 161-Z, available at: http://www.pravo.by/pdf/2006-122/2006-122(006-101).pdf\#page=29 (October 11, 2017)

${ }^{3}$ Ob utverzhdenii Polozhenija o porjadke hranenija, transportirovki, izjatija iz obrashhenija, vozvrata proizvoditelju ili postavshhiku, unichtozhenija lekarstvennyh sredstv, dopolnenii, izmenenii i priznanii utrativshimi silu nekotoryh postanovlenij Soveta Ministrov Respubliki Belarus - Postanovlenie ot 22.12.2009 No 1677 (Resolution of the Council of Ministers of the Republic of Belarus), Nacional'nyj reestr pravovyh aktov Respubliki Belarus', 14.01.2010, No 6, st., 5/30980, available at http://etalonline.by/?type=text\&regnum=c20901677\#load_text_none_1_(October 11, 2017) 4 Dogovor o Evrazijskom ekonomičeskom sojuze, 29.05.2014, available at: http://pravo.by/document/?guid=12551\&p0=F01400176\&p1=1\&p5=0 (October 11, 2017)

${ }^{5}$ Soglashenie o edinyh principah i pravilah obrashhenija lekarstvennyh sredstv v ramkah Evrazijskogo jekonomicheskogo sojuza), 23.12.2014, available at: http://www.pravo.by/document/?guid=3871\&p0=f01400350 (October 11, 2017)

${ }^{6}$ Convention on the Counterfeiting of Medical Products and Similar Crimes involving Threats to the Public Health, 28.11.2011, available at: http://www.coe.int/en/web/conventions/full-list/-/conventions/rms/090000168008482f. (October 11, 2017)

${ }^{7}$ Soglashenie o sotrudnichestve v bor'be s obrashheniem fal'sificirovannyh lekarstvennyh sredstv, concluded in Chisinau on 14.11.2008, available at: http://online.zakon.kz/Document/?doc_id=30433637\#pos=7;-104. (October 11, 2017)

${ }^{8}$ Soglashenie o edinyh principah i pravilah obrashhenija lekarstvennyh sredstv v ramkah Evrazijskogo jekonomicheskogo sojuza, 23.12.2014, available at: http://www.pravo.by/document/?guid=3871\&p0=f01400350 (October 11, 2017)

9 Reshenie No 86 O Porjadke vzaimodejstvija gosudarstv - chlenov Evrazijskogo jekonomicheskogo sojuza po vyjavleniju fal'sificirovannyh, kontrafaktnyh i (ili) nedobrokachestvennyh lekarstvennyh sredstv), Astana, 03.11.2016, available at: http://docs.cntd.ru/document/456026105 (October 11, 2017)

${ }^{10} \mathrm{Ob}$ utverzhdenii Polozhenija o porjadke hranenija, transportirovki, izjatija iz obrashhenija, vozvrata proizvoditelju ili postavshhiku, unichtozhenija lekarstvennyh sredstv, dopolnenii, izmenenii i priznanii utrativshimi silu nekotoryh postanovlenij Soveta Ministrov Respubliki Belarus - Postanovlenie ot 22.12.2009 No 1677 (Resolution of the Council of Ministers of the Republic of Belarus), Nacional'nyj reestr pravovyh aktov Respubliki Belarus', 14. 1. 2010, No 6, st., 5/30980, available at http://etalonline.by/?type=text\&regnum=c20901677\#load_text_none_1_ .(October 11, 2017)

11 Federal'nyj zakon "Ob obrashhenii lekarstvennyh sredstv"), 12.04.2010 No 61-FZ, available at: http://www.consultant.ru/document/cons_doc_LAW_99350/ (October 11, 2017) 
12 Kodeks Respubliki Kazahstan o zdorov'e naroda i sisteme zdravoohranenija, 2009, available at: https://online.zakon.kz/Document/?doc_id=30479065 (October 11, 2017)

${ }^{13}$ Reshenie No 80 Ob utverzhdenii Pravil nadlezhashhej distrib'jutorskoj praktiki v ramkah Evrazijskogo jekonomicheskogo sojuza, Astana, 03.11.2016, available at: http://www.eurasiancommission.org/ru/act/texnreg/deptexreg/LS1/Documents/27.pdf (October 11, 2017)

14 Reshenie No 86 O Porjadke vzaimodejstvija gosudarstv - chlenov Evrazijskogo jekonomicheskogo sojuza po vyjavleniju fal'sificirovannyh, kontrafaktnyh i (ili) nedobrokachestvennyh lekarstvennyh sredstv), Astana, 03.11.2016, available at: http://docs.cntd.ru/document/456026105 (October 11, 2017)

${ }^{15}$ Explanatory Report to the Council of Europe Convention on the counterfeiting of medical products and similar crimes involving threats to public health, 2011, available at: https://rm.coe.int/16800d383b (October 11, 2017)

16 Ugolovno-processual'nyj kodeks Respubliki Belarus, 16.07.1999, available at: http://etalonline.by/?type=text\&regnum=HK9900295\#load_text_none_1_ (October 11, 2017)

17 Zakon Respubliki Belarus O zdravoohranenii, 18.06.1993 No 2435-XII, available at: http://pravo.by/document/?guid=3871\&p0=v19302435 (October 11, 2017)

18 Ugolovnyj kodeks Rossijskoj Federacii, 1996, available at: http://www.consultant.ru/document/cons_doc_LAW_10699/(October 11, 2017)

${ }^{19}$ Kodeks Respubliki Belarus ob administrativnyh pravonarushenijah, 21.04.2003, available at: http://www.pravo.by/document/?guid=3871\&p0=hk0300194 (October 11, 2017)

20 Kodeks Rossijskoj Federacii ob administrativnyh pravonarushenijah, 30.12.2001, available at: http://www.consultant.ru/document/cons_doc_LAW_34661/ (October 11, 2017)

${ }^{21}$ United Nations Convention against Transnational Organized Crime and the Protocols Thereto. New York, 2004. available at: https://www.unodc.org/documents/treaties/UNTOC/Publications/TOC\%20Convention/TO Cebook-e.pdf (October 11, 2017)

22 Ugolovno-processual'nyj kodeks Respubliki Belarus, 16.07.1999, available at: http://etalonline.by/?type=text\&regnum=HK9900295\#load_text_none_1_ (October 11, 2017)

${ }^{23}$ Zakon Respubliki Belarus', O meždunarodnoj pravovoj pomošči po ugolovnym delam, 04.01.2008, No 284-Z, available at: http://zakon.by/pdf/2004-87/2004-87(029-047).pdf (October 11, 2017)

${ }^{24}$ Soglashenie o pravovoj pomoshhi i vzaimodejstvii tamozhennyh organov gosudarstv chlenov tamozhennogo sojuza po ugolovnym delam i delam ob administrativnyh pravonarushenijah), Astana, 05.07.2010, available at: http://www.consultant.ru/document/cons_doc_LAW_170241 (October 11, 2017)

\section{References}

Ahramenka, N. F. [et al] (2010) Nauchno-prakticheskij kommentarij k Ugolovnomu kodeksu Respubliki Belarus (Minsk: GIUST BGU).

Aksenova-Sorohtej J., Baranovskaja E., Belaja O. \& Knjazeva E. (2016) Nekotorye Aktual'nye Aspekty Dekriminalizacii Farmacevticheskogo Rynka Rossijskoj Federacii, Uspehi sovremennoj nauki, 8(3), pp. 144-148.

Godunov, O. I. (2015) K voprosu o realizacii ugolovnoj otvetstvennosti za oborot 
fal'sificirovannyh lekarstvennyh sredstv, Nauchnyj poisk, 1(5), pp. 5-7.

Kagadeeva, S. O. (2015) Problema fal'sifikacii lekarstvennyh sredstv na territorii RF, Medicinskoe pravo: teorija i praktika, 1, pp. 425-430.

Khasanov, F. Z (2015) Ugolovnaja otvetstvennost za obrashhenie falsificirovannyh lekarstvennyh sredstv, Medicinskoe pravo,1, pp. 49 - 51.

Klimenko, T.M. \& Tretjakova E.I. (2015) Mezhdunarodnoe sotrudnichestvo v oblasti protivodejstvija oborotu fal'sificirovannyh lekarstvennyh sredstv, In: Kriminalistika: vchera, segodnja, zavtra Sbornik nauchnyh trudov, pp. 114-119 (Vostochno-Sibirskij institut MVD Rossii).

Kopytin, D. A. (2012) Bor'ba s fal'sificirovannymi lekarstvennymi preparatami v Evropejskom Sojuze i v Rossii, Remedium. Zhurnal o rossijskom rynke lekarstv $i$ medicinskoj tehnike, 9, pp. 8-13.

Maksimov, S. V. (2014) Fal'sifikacija lekarstvennyh sredstv v Rossii i perspektivy ratifikacii Konvencii Soveta Evropy «Medikrim», Trudy Instituta gosudarstva i prava Rossijskoj akademii nauk, 3, pp. 75-87.

Reutskaja, L. A. (2016) Mezhdunarodnoe sotrudnichestvo Ministerstva zdravoohranenija v sfere obrashhenija lekarstvennyh sredstv, In: Reutskaja, L. A. (ed.) Aktualnye voprosy farmacii Respubliki Belarus, V. 2, ch. 1 (Minsk: BGMU).

Rocheva, E. A. (2014) Projavlenija korrupcii v sfere zdravoohranenija, available at: https://www.consultant.ru/sys/ (August 8, 2017).

Rocheva, E.A. (2016) K voprosu o protivodejstvii obrashheniju fal'sificirovannyh lekarstvennyh sredstv, Voprosy kriminologii, kriminalistiki i sudebnoj jekspertizy, 40(2), pp. 47-52.

Kostiukevich, N. (2017) Dlja vseh jeto biznes. Kak v Belarusi pytajutsja snizit' ceny na importnye lekarstva, available at: https://news.tut.by/society/563184.html (October 5, 2017).

Sharova, G. N. (2009) Fal'sificirovannye lekarstvennye sredstva kak ugroza bezopasnosti zhizni i zdorov'ju naselenija, Vestnik Akademii General'noj prokuratury Rossijskoj Federacii, 2(10), pp. 27-32.

Sherjakov, A. A. (2009) Standartizacija i kontrol' kachestva lekarstvennyh sredstv v Belorussii Soobshhenie 3. Problemy fal'sifikacii lekarstvennyh sredstv, Vestnikfarmacii, 4(46), pp. 75-79.

Shornikov, E. I. (2011) Problemy falsifikacii lekarstvennyh sredstv, Obrazovanie. Nauka. Nauchnye kadry, 2, pp. 36-38.

Strban, G. (2016) Supervision of Medical Activities, Medicine, Law \& Society, 9(1), pp. 4158. 